\title{
Analysis of Farmers' Attitudes to Gm Crops in the Cameron Highlands
}

\author{
Ahmad Firdhaus Arham 1 , Mohamed Faizal Noor Batcha², Latifah Amin ${ }^{1,2}$, Muhammad \\ Adzran Che Mustapa', Zurina Mahadi', Mashitoh Yaacob', Noor Ashikin Mohamed \\ Yusoff $^{3}$, Nor Asiah Omar ${ }^{4}$ and Wan Hirwani Wan Hussain ${ }^{5}$ \\ ${ }^{1}$ Pusat Citra Universiti, Universiti Kebangsaan Malaysia, Malaysia, 43600 UKM Bangi, Selangor, Malaysia \\ ${ }^{2}$ The Institute of Islam Hadhari (HADHARI), Universiti Kebangsaan \\ Malaysia, 43600 UKM Bangi, Selangor, Malaysia. \\ ${ }^{3}$ Perdana School of Science, Technology and Innovation Policy \\ Universiti Teknologi Malaysia 54100 Kuala Lumpur. \\ ${ }^{4}$ Faculty of Economics and Management, Universiti Kebangsaan \\ Malaysia, 43600 UKM Bangi, Selangor, Malaysia. \\ ${ }^{5} U K M-G r a d u a t e$ School of Business, Universiti Kebangsaan \\ Malaysia, 43600 UKM Bangi, Selangor, Malaysia.
}

\section{ABSTRACT}

The objective of this paper was to identify the factors influencing the attitudes of Malaysian farmers in the Cameron Highlands, Pahang, Malaysia, towards Genetically Modified (GM) crops. The survey was conducted between December 2019 and February 2020. Using a simple random sampling method, 348 questionnaires were distributed personally to vegetable farmers in the Cameron Highland by trained enumerators. However, only 176 complete and valid responses were retained for analysis. Descriptive and linear regression analyses were performed using the Statistical Package for Social Sciences (SPSS ${ }^{\circledR}$ ) software, Version 24. The results showed that the farmers have high self-efficacy when it comes to farming GM crops, acknowledged the great benefits of GM crops, rated the cost of farming such crops as moderate, and expressed a highly positive attitudes towards GM crops. However, they were also cautious about GM crops in that they perceived them as having moderate risks and a moderate fit with existing farming practices. Additionally, they claimed that government support and market demand were low. Regression analyses indicated that six factors have a significant relationship with attitudes to GM crops, with perceived self-efficacy as the strongest predictor, followed by government support, perceived cost, perceived risks, perceived benefits, and market demand. The results have valuable implications for the future growth of agricultural biotechnology in Malaysia and in other developing countries with a similar culture.

\section{KEY WORDS: FARMERS’ ATTITUDES; PREDICTIVE FACTORS; GM CROPS; CAMERON HIGHLANDS.}

\section{ARTICLE INFORMATION}

*Corresponding author email: nilam@ukm.edu.my

Received 12th Oct 2020 Accepted after revision 26th Dec 2020 Print ISSN: 0974-6455 Online ISSN: 2321-4007 CODEN: BBRCBA

Thomson Reuters ISI Web of Science Clarivate Analytics USA and Crossref Indexed Journal

$$
\underset{\text { Analytics }}{\text { Clarivate }}
$$

NAAS Journal Score 2020 (4.31)

A Society of Science and Nature Publication, Bhopal India 2020. All rights reserved.

Online Contents Available at: http//www.bbrc.in/

Doi: http://dx.doi.org/10.21786/bbrc/13.15/44

\section{INTRODUCTION}

Genetic modification is a biological technique involving the genetic modification of living organisms with regard to specific functions (Zhang et al., 2016). Today, there is a great deal of research and the production of genetically modified products, especially in the commercialization and production of agricultural products (World Bank, 2017). Agricultural production involving GM crops can 
reduce the issue of malnutrition or hunger, and make the crop better and more nutritious (Hafsyah and Ristawati, 2020). Conversely, some researchers argue that GM crops can affect the environment and the socio-economy of a country (Dale, 2002), thus raising the question of its safety (Raman, 2017). However, GM crops are continuing to develop rapidly and attract controversy around the world (Deng et al., 2019; Andrew et al., 2018).

Figure 1: Research Conceptual Framework

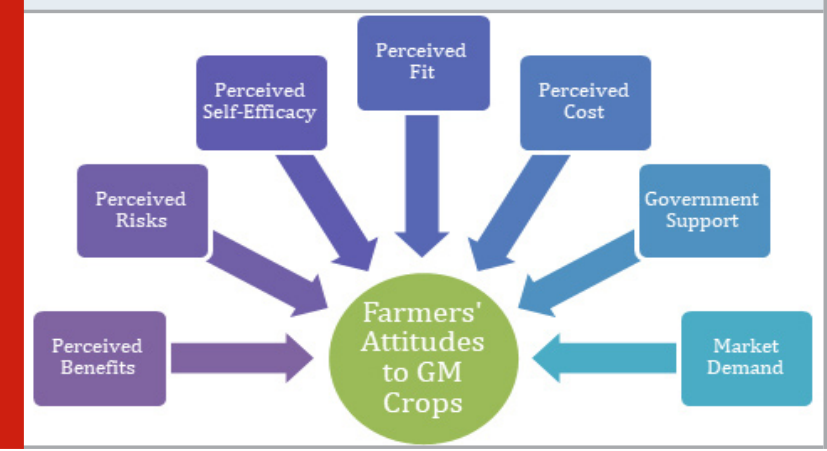

Table 1. Demographic Profiles of Respondents $(n=399)$

\begin{tabular}{l|c|c|c|}
\hline \multirow{2}{*}{ Items } & & $\begin{array}{c}\text { Frequency } \\
\text { (n) }\end{array}$ & $\begin{array}{c}\text { Percentage } \\
\text { (\%) }\end{array}$ \\
\hline \multirow{2}{*}{ Gender } & Male & 138 & 78.4 \\
& Female & 38 & 21.6 \\
\hline Race & Indian & 68 & 38.6 \\
& Chinese & 56 & 31.8 \\
& Malay & 52 & 29.5 \\
\hline Religion & Hindu & 52 & 29.5 \\
& Buddha & 51 & 29.0 \\
& Islam & 44 & 25.0 \\
\hline Age (years old) & Christian & 29 & 16.5 \\
& Above 45 years & 67 & 38.1 \\
& 36-45 years & 66 & 37.5 \\
& Under 35 years & 43 & 24.5 \\
\hline Level of & Secondary schools & 106 & 60.2 \\
Education & Diploma/ & 47 & 26.7 \\
& Pre-University & & \\
& University & 23 & 13.1 \\
\hline
\end{tabular}

In Malaysia, the agricultural industry is one of the main features of the country's economy, especially in terms of increasing the income of farmers (Hafsyah and Ristawati, 2020). Since 1985, Malaysia has been working on the development of GM crops, inspired by the rich biodiversity of the country (Bakar, 2007; Arujanan, 2016). However, Malaysia has not planted any GM crops commercially because GM research activities is still in its early stages (Andrew et al., 2018). Therefore, this study will focus on the attitudes of Malaysian vegetable farmers in the Cameron Highlands. It intends to answer two key research questions: What are the attitudes of Malaysian farmers towards GM crops, and what are the significant predictive factors that influence such attitudes?
Research Conceptual Framework: The instrument for this study was based on the Technology Acceptance Model (TAM), which has been frequently used in technologyacceptance studies. Seven variables (predictive factors) were included in the framework, namely perceived benefits and risks (Amin et al., 2014), perceived selfefficacy (Hosseini et al., 2016; Syan et al., 2019), perceived fit (Lau and Phau, 2006; Volckner and Sattler et al., 2006), perceived cost (Mwangi and Kariuki, 2015), government support, and market demand (Deng et al., 2019). It was hypothesized that these influence farmers' attitudes to the adoption of GM crops (see Figure 1).

\section{METHODOLOGY}

This is a quantitative study of data gathered using questionnaires. The questionnaire was a multidimensional instrument that identifies the predictive factors influencing the attitudes of farmers to the adoption of GM crops. A 7-point Likert-style scale ranging from 1 (strongly disagree) to 7 (strongly agree) was used to assess all items used in this analysis. The questionnaires were administered personally by the research team members and by trained enumerators to a sample of Malaysian farmers in the Cameron Highlands, Pahang from December 2019 to February 2020. Prior to the survey, the enumerators briefly described the context of the study and introduced the respondents to the basics, and to examples of GM crops, to make it easier for them to respond appropriately.

A total of 348 questionnaires were distributed to the farmers involved, using a simple random sampling process, but only 176 complete and valid responses were retained for analysis. According to the recommendations by UCLA (2016), G*Power 3.1.9.2 software was used to calculate appropriate sample size. By using the power of 0.70 to 0.80 , the effect of the size ( $f=0.0577$; large) and the significance level $(p=0.05)$, the results gave a range of sample sizes ranging from 109 to 138, depending on power. Consequently, 176 responses were deemed to be good enough for this research. Table 1 shows the demographic characteristics of the respondents.

The Statistical Package for Social Sciences (SPSS ${ }^{\circledR}$ ) software was used to analyse all the response data. The process of analysis begins with data reliability analysis (Croncbach's Alpha) and the validity measures (factor loadings) of the constructs. All the variables achieved more than 0.60 in terms of Cronbach's Alpha coefficients. This indicated an acceptable level of internal consistency as suggested by Hair et al. (2014). The standardized loadings of all items were greater than 0.5 , indicating a good validity (Hair et al. 2010). Pearson's correlation analyses were performed prior to regression. Only those factors that have a significant correlation with attitude to GM crops were included in the regression analyses.

\section{RESULTS AND DISCUSSION}

Mean Scores and Correlation Analysis: The farmers rated themselves as possessing high levels of self-efficacy to 
farm GM crops (mean score $=5.60$ ), perceived GM crops as offering substantial benefits (mean score $=5.35$ ) and were highly positive with regard to GM crops (mean score $=5.12$ ) (Figure 2). Positive support with regard to the management of GM crops promises to deal with current and future problems in the commercialization of agriculture but a growing market trend has been beneficial to farmers, and offers benefits for consumers and for the national economy (Raman, 2017). Additionally they claimed that the farming of GM crops will have a moderate fit with their existing farming practices (mean score $=4.93$ ) and will incur moderate costs (mean score = 3.58). On the other hand, they were also cautious in terms of their views with regard to GM crops in that they acknowledged the existence of moderate risks (mean score $=3.48$ ). It is rather worrying that the farmers felt that government support was minimal (mean score $=2.29$ ) and assumed that there was also much less market demand for the outcomes of this technology (mean score $=2.94$ ).

Figure 2: Mean Score of Farmers' Attitudes to GM Crops

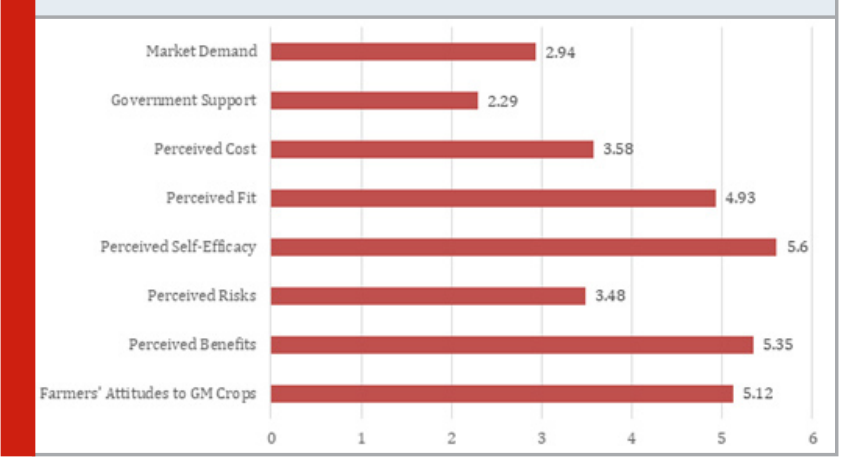

As suggested by Cheung and Chan (2005), Pearson correlation analysis was performed to establish the association between all variables and attitude to GM crops. Table 2 indicates a positive correlation between perceived benefits and attitude towards GM crops ( $\mathrm{r}=$
0.473, $p=0.000$ ) and a negative relationship between perceived risks and attitude towards this technology $(\mathrm{r}$ $=-0.423, p=0.000)$. Perceived self-efficacy $(r=0.380$, $\mathrm{p}=0.000)$ and perceived fit $(\mathrm{r}=0.333, \mathrm{p}=0.000)$ also indicated a positive correlation with the attitude towards GM crops. At the same time, perceived cost showed a significantly negative association with the attitude towards GM crops $(\mathrm{r}=-0.466, \mathrm{p}=0.000)$. On the other hand, government support ( $\mathrm{r}=0.145, \mathrm{p}=0.027)$ and market demand $(r=0.347, p=0.000)$ have a significantly positive relationship with attitudes to GM crops.

Multiple Regression Analysis: Table 3 shows that $51.3 \%$ of the variation in attitude towards GM crops is influenced by perceived benefits, perceived cost, market demand, perceived self-efficacy, government support and perceived risk. The value of $\mathrm{R} 2=0.224$ indicates that $22.4 \%$ of the change in attitude towards GM crops is due to changes caused by perceived benefits. The combination of benefits and costs is felt to contribute by $35.1 \%$ in attitudes toward this technology. Market demand and self-efficacy contributed an additional contribution of $4.6 \%$ and $6.9 \%$ variance respectively, in terms of attitudes. At the same time, government support contributed $2.0 \%$ variance and perceived risk contributed $2.7 \%$ variance.

A total of $48.7 \%$ change in criterion factors may be due to other factors not considered in this study. As suggested by Sulaiman et al. (2014), an adjusted value of R2 smaller than R2 (0.017 or 1.7\%) describes the extent to which the model formed can be generalized to the population ideally. Meanwhile, the Standard Error of the Estimate explains that the smaller the value the better, because the model will be more accurate in anticipating the dependent variable According to the results, perceived benefits, perceived risks, perceived self-efficacy, perceived costs, government support and market demand were found to contribute significantly to attitudes toward GM crops. At the same time, perceived fit did not contribute significantly to farmers' attitudes to GM crops.

Table 2. The Correlation Matrix among Predictive Factors with Farmers' Attitudes to GM Crops

\begin{tabular}{l}
\begin{tabular}{l|c|c|c|c|c|c|c|c|}
\hline & Attitudes & PB & PR & PSE & PF & PC & GS & MD \\
\hline \multirow{2}{*}{ Attitudes } & 1 & $0.473^{* *}$ & $-0.423^{* *}$ & $0.380^{* * *}$ & $0.333^{* *}$ & $-0.466^{* *}$ & $0.145^{*}$ & $0.347^{* * *}$ \\
\cline { 2 - 9 } & 0.000 & 0.000 & 0.000 & 0.000 & 0.000 & 0.027 & 0.000 \\
\cline { 2 - 8 } & 176 & 176 & 176 & 176 & 176 & 176 & 176 & 176 \\
\hline
\end{tabular} \\
Notes: Perceived Benefits (PB), Perceived Risks (PR), Perceived Self-Efficacy (PSE), Perceived Fit (PF), Perceived \\
Cost (PC), Government Support (GS), Market Demand (MD); ${ }^{*}$ p < $0.05,{ }^{* * *}$ p < 0.01 (2-tailed) \\
\hline
\end{tabular}

ANOVA test was carried out to determine whether or not the combination of the six predictive factors has a direct effect on attitudes to GM crops in this study model. Based on Table 4, it would appear that the combination of six predictor factors contributes significantly to the attitude towards GM crops $[F(6,169)=29.657, p=0.000]$.
Regression Analysis: Table 5 presented the path coefficient values to determine the strength of the association between predictive factors and attitudes to GM crops. The most important factor of attitudes toward GM crops was perceived to be self-efficacy $(\beta=0.397$, $t=6.104, p=0.000)$. This result revealed that farmers 
would have a more positive attitudes toward GM crops if they perceived greater self-efficacy related to the farming of GM crops. Ardekani et al. (2020) and Bimbo et al. (2017) highlighted the importance of this factor in determining the willingness of consumers to adopt GM foods and dairy products.

Table 3. Direct effect of Predictor Factors on Farmers' Attitudes to GM Crops

\begin{tabular}{|c|c|c|c|c|}
\hline $\begin{array}{l}\text { Model Summary } \\
\text { Model }\end{array}$ & $\mathrm{R}$ & R Square & $\begin{array}{l}\text { Adjusted } \\
\text { R Square }\end{array}$ & $\begin{array}{l}\text { Std. Error of } \\
\text { the Estimate }\end{array}$ \\
\hline 1: (Constant), Perceived Benefits & 0.473 & 0.224 & 0.219 & 0.625 \\
\hline 2: (Constant), Perceived Benefits, Perceived Cost & 0.592 & 0.351 & 0.343 & 0.573 \\
\hline 3: (Constant), Perceived Benefits, Perceived Cost, Market Demand & 0.630 & 0.397 & 0.387 & 0.554 \\
\hline $\begin{array}{l}\text { 4: (Constant), Perceived Benefits, Perceived Cost, Market Demand, } \\
\text { Perceived Self-Efficacy }\end{array}$ & 0.683 & 0.466 & 0.453 & 0.523 \\
\hline $\begin{array}{l}\text { 5: (Constant), Perceived Benefits, Perceived Cost, Market Demand, } \\
\text { Perceived Self-Efficacy, Government Support }\end{array}$ & 0.697 & 0.486 & 0.471 & 0.515 \\
\hline $\begin{array}{l}\text { 6: (Constant), Perceived Benefits, Perceived Cost, Market Demand, } \\
\text { Perceived Self-Efficacy, Government Support, Perceived Risks }\end{array}$ & 0.716 & 0.513 & 0.496 & 0.503 \\
\hline
\end{tabular}

Government support $(\beta=0.276, \mathrm{t}=3.495, \mathrm{p}=0.001)$ was listed as the second most important predictor of attitudes towards GM crops. Kikulwe et al. (2011) indicated that increasing government encouragement would effectively enhance the satisfaction related to GM crops. Perceived risks $(\beta=-0.238, t=-3.033, p=0.003)$ were the third most important predictor of attitudes toward GM crops. These results indicated that if farmers considered there were greater risks associated with GM crops, they would be less likely to adopt GM crops.

Table 4. ANOVA for Regression Analysis (Model Fit)

\begin{tabular}{|l|c|c|c|c|l|}
\hline & $\begin{array}{c}\text { Sum of } \\
\text { Squares }\end{array}$ & df & $\begin{array}{c}\text { Mean } \\
\text { Square }\end{array}$ & F & Sig. \\
\hline Regression & 44.948 & 6 & 7.491 & 29.615 & $0.000 \mathrm{~g}$ \\
\hline Residual & 42.688 & 169 & .253 & & \\
\hline Total & 87.636 & 175 & & & \\
\hline
\end{tabular}

Notes: g (Constant), Perceived Benefits, Perceived Cost, Market Demand, Perceived Self-Efficacy, Government Support, Perceived Risks

The next most significant predictors of attitudes to GM crops were the factor of perceived cost $(\beta=-0.194, t$ $=-2.546, p=0.012$ ), followed by perceived benefits $(\beta=0.150, t=2.190, p=0.030)$ and market demand $(\beta=0.172, t=2.184, p=0.030)$. Brown and Russell (2007) suggested that cost eventually impacts the decision to adopt any new technology. Amin et al. (2014) also confirmed the results of this study, which found that perceived benefits contribute significantly to attitudes to GM rice. Lence and Hayes (2020) clarified that when GM technology was introduced in the US in terms of corn production, it led to savings in costs, and

\begin{tabular}{|c|c|c|c|c|}
\hline $\begin{array}{l}\text { Coefficients } \\
\text { Factors }\end{array}$ & B & $\begin{array}{c}\text { Beta } \\
(\beta)\end{array}$ & $\mathrm{t}$ & $\begin{array}{l}\text { Significant } \\
\text { Value }\end{array}$ \\
\hline $\begin{array}{l}\text { Farmers' Attitudes to } \\
\text { Adopt GM Crops } \\
\text { (Constant) }\end{array}$ & 3.547 & & 8.490 & $0.000^{* *}$ \\
\hline Perceived Self-Efficacy & 0.256 & 0.397 & 6.104 & $0.000^{* * *}$ \\
\hline Government Support & 0.117 & 0.276 & 3.495 & $0.001^{* * *}$ \\
\hline Perceived Risks & -0.168 & -0.238 & -3.033 & $0.003^{* * *}$ \\
\hline Perceived Cost & -0.130 & -0.194 & -2.546 & $0.012^{*}$ \\
\hline Perceived Benefits & 0.125 & 0.150 & 2.190 & $0.030^{*}$ \\
\hline Market Demand & 0.086 & 0.172 & 2.184 & $0.030^{*}$ \\
\hline
\end{tabular}

that market demand depended on consumers' concerns about GM products. Therefore, if the market demand for GM crops is higher, this will support the adoption of this technology.

\section{CONCLUSION}

The study results confirm that six factors have significant roles to play in shaping farmers' attitudes to GM crops, with perceived self-efficacy being the strongest predictor, followed by government support, perceived cost, perceived risks, perceived benefits, and market demand. By looking at the highly positive attitude on the part of the farmers in this sample towards GM crops, and their strong perceived self-efficacy to farming GM crops, there is a positive indication that the future adoption of GM crops in Malaysia will be supported by Malaysian farmers. However there is a need to look 
seriously at possible hindrance factors, notably the low level of government support, low market demand as perceived by the farmers, and possible risks. By working on improving these issues, the Malaysian government could create a strong enabling environment leading to Malaysia adopting GM crops.

\section{ACKNOWLEDGMENTS}

The authors would thank all respondents who have participated in this research. The research was financially supported by Universiti Kebangsaan Malaysia under the MI-2020-010 and DCP-2017-005/2 grants.

\section{REFERENCES}

Amin, L., Azad, M.A.K., Azlan, N.A.A., and Zulkifli, F. (2014) Factors influencing stakeholders' attitudes toward cross-kingdom gene transfer in rice. New Genetics and Society., 33(4), 370-399. https://doi.org/10.1080/1463 6778.2014 .951992

Andrew, J., Ismail, N.W., and Djama, M. (2018), An overview of genetically modified crop governance, issues and challenges in Malaysia. Journal of the Science of Food and Agriculture., 98(1), 12-17. https:// doi.org/10.1002/jsfa.8666.

Ardekani, Z.F., Akbari, M., Pino, G., Zuniga, M.A. and Azadi, H. (2020) Consumers' willingness to adopt genetically modified foods, British Food Journal., Vol. ahead-of-print No. ahead-of-print. https://doi. org/10.1108/BFJ-04-2019-0260

Bimbo, F., Bonanno, A., Nocella, G., Viscecchia, R., Nardone, G., Devitiis, B.D., Carlucci, D. (2017), Consumers' acceptance and preferences for nutritionmodified and functional dairy products: A systematic review, Appetite., 113, 141-154. https://doi.org/10.1016/j. appet.2017.02.031.

Brown, I. and Russell, J. (2007), Radio frequency identification technology: An exploratory study on adoption in the South African retail sector. International Journal of Information Management., 27(4), 250-265. https://doi.org/10.1016/j.ijinfomgt.2007.02.007

Cheung, M.W. and Chan, W. (2005), Meta-analytic structural equation modelling: A two-stage approach, Psychol. Methods., 10(1), 40-64.

Dale, P.J. (2002), The environmental impact of genetically modified (GM) crops: A review. The Journal of Agricultural Science., 138(3), (2002) 245-248. https:// doi.org/10.1017/S0021859602001971

Deng, H., Hu, R., Pray, C. and Jin, Y. (2019), Perception and Attitude toward GM Technology among Agribusiness Managers in China as Producers and as Consumers. Sustainability., 11(5), 1342. https://doi. org/10.3390/su 11051342

Hafsyah, S., and Ristawati, R. (2020), Food security of genetically modified crops: the roles of the states in Malaysia and indonesia to protect farmers' rights. Journal of Critical Reviews., 7(3), 336-343. http://dx.doi. org/10.31838/jcr.07.03.66

Hair, J.F., Black, W.C., Babin, B.J. and Anderson, R.E. (2010), Multivariate data analysis: A Global Perspective. Pearson Prentice Hall: New York.
Hair, J.F., Sarstedt, M., Hopkins, L. and Kuppelwieser, V.G. (2014), Partial least squares structural equation modeling (PLS-SEM): An emerging tool in business research. European Business Review., 26(2), 106-121.

Hosseini, M.R., Banihashemi, S., Chileshe, N., Namzadi, M.O., Udaeja, C., Rameezdeen, R., McCuen T. (2016), BIM adoption within Australian small and medium-sized enterprises (SMEs): An innovation diffusion model. Construction Economics and Building., 16(3), 71-86. https://doi.org/10.5130/AJCEB.v16i3.5159

Kikulwe, E.M., Wesseler, J. and Falck-Zepeda, J. (2011), Attitudes, perceptions, and trust. Insights from a consumer survey regarding genetically modified banana in Uganda. Appetite., 57(2), 401-413. https:// doi.org/10.1016/j.appet.2011.06.001

Lau, K.C. and Phau, I. (2006), Perceptual Fit in Symbolic Brands: Evaluation From a Brand Personality Perspective, in AP - Asia-Pacific Advances in Consumer Research Volume 7, eds. Margaret Craig Lees, Teresa Davis, and Gary Gregory, Sydney, Australia: Association for Consumer Research., 144-145.

Lence, S. and Hayes, D. (2005), Genetically Modified Crops: Their Market and Welfare Impacts. American Journal of Agricultural Economics., 87(4), 931-950. Retrieved December 25, 2020, from http://www.jstor. org/stable/3697781

Mwangi, M., and Kariuki, S. (2015), Factors Determining Adoption of New Agricultural Technology by Smallholder Farmers in Developing Countries. Journal of Economics and Sustainable Development., 6(5), 208-216.

Raman, R. (2017), The impact of Genetically Modified (GM) crops in modern agriculture: A review, GM Crops Ct Food., 8(4), 195-208. https://doi.org/10.1080/21645 698.2017.1413522

Sulaiman, W.I.W. and Mahbob, M.H. (2014), Kesignifikanan Model Kepuasan Komunikasi Dalam Konteks Pengurusan Maklumat Sektor Awam (The Significance of The Communication Satisfaction Model in The Public Sector Information Management Context). Malaysian Journal of Communication., 30(1), 97-115. Syan, A.S., Kumar, V., Sandhu, V. and Hundal, B.S. (2019), Empirical Analysis of Farmers' Intention to Adopt Sustainable Agricultural Practices. Asia-Pacific Journal of Management Research and Innovation., 15(1-2), 39-52. https://doi.org/10.1177/2319510x19848857

UCLA: Statistical Consulting Group. Multiple regression power analysis, G*Power data analysis examples, [Accessed 2016 August 22) Available from: https://stats. idre.ucla.edu/other/gpower/multiple-regression-poweranalysis/

Volckner, F. and Sattler, H. (2006), Drivers of brand extension success. Journal of Marketing., 70(2), 18-34. https://doi.org/10.1509/jmkg.70.2.018

World Bank. (2017), Agriculture, value added (current US\$). [cited 2021 Nov 21]. Available from http://data. worldbank.org/indicator/NV.AGR.TOTL.CD

Zhang, C., Wohlhueter, R. and Zhang, H. (2016), Genetically modified foods: A critical review of their promise and problems. Food Science and Human Wellness., 5(3), 116-123. https://doi.org/10.1016/j. fshw.2016.04.002 